\title{
Factors determining the soil available water during the last two decades (1997-2019) in southern Spain
}

\author{
José A. Sillero-Medina ${ }^{1}$ (D) $\cdot$ Jesús Rodrigo-Comino ${ }^{2}$ (D) $\cdot$ José $^{D}$. Ruiz-Sinoga ${ }^{1}$ (D) \\ Received: 20 November 2020 / Accepted: 14 August 2021 / Published online: 8 September 2021 \\ (C) The Author(s) 2021
}

\begin{abstract}
Assessing soil hydrological conditions can provide essential information for understanding the environmental processes that affect ecosystem services and, particularly in the context of ongoing climate change. This is key in areas affected by water scarcity such as the Mediterranean belt. Therefore, the main goals of this research are (i) to assess the main rainfall dynamics and trends of some representative hotspots along with southern Spain and (ii) to determine the impact on the soil available water content (AWC) over the last two decades. An analysis of daily precipitation and soil hydrological conditions was combined with soil sampling (543) and laboratory analyses to evaluate the properties related to the soil infiltration and retention capacity. The results show that the organic factors control soil properties and their hydrodynamics in southern Spain. Furthermore, a general declining trend in soil water availability is observed over the last two decades. This is more extreme in arid and semi-arid areas, where there have been several years in the last decade with more than 200 days without the available water content. Moreover, in these areas, heavy rainfall during specific moments of the year is the key factor that manifests a greater incidence in areas with steeper slopes, which in turn, also conditions the biological factors and the hydrodynamics of the soil. In short, in the context of climate change, the analysis of soil hydrological dynamics could be used to identify biodiversity thresholds in the Mediterranean area and even to detect phenological changes in specific plant species.
\end{abstract}

Keywords Regional studies $\cdot$ Climate change $\cdot$ Mediterranean belt $\cdot$ Soil dry periods

\section{Introduction}

The Mediterranean climate is characterized by dry summers; therefore, the native vegetation must adapt to increasingly frequent and recurring conditions of water stress (Klausmeyer and Shaw 2009; Nardini et al. 2014). Some

Responsible Editor: Amjad Kallel

Jesús Rodrigo-Comino

jesusrc@ugr.es

José A. Sillero-Medina

jasillero@uma.es

José D. Ruiz-Sinoga

sinoga@uma.es

1 Departamento de Geografía, Universidad Málaga, Campus de Teatinos, 29071 Málaga, España

2 Departamento de Análisis Geográfico Regional y Geografia Física, Facultad de Filosofía y Letras, Campus Universitario de Cartuja, Universidad de Granada, 18071 Granada, España authors claimed that this situation will impact pasture (Dlamini et al. 2016; Abdalla et al. 2018), crop productivity (Rodrigo-Comino et al. 2021), and plant mortality (Peñuelas et al. 2001; Bréda et al. 2006), and, as a consequence, it will enhance the fuel for forest fires (Vidal et al. 1994; AlcasenaUrdíroz et al. 2019; Martínez-Torres et al. 2019; FernandezAnez et al. 2021). Thus, an increase in the intensity or frequency of droughts can limit productivity and the ecological and economic values of this fragile ecosystem (Guillot et al. 2019; Lobo Do Vale et al. 2019). Some authors confirm that timely and accurate monitoring of soil moisture and vegetation is necessary to inform early warning services, assess droughts, and develop efficient management plans that reduce economic and environmental vulnerabilities (Guo et al. 2019; He et al. 2017).

The soil water balance has been traditionally used to estimate various soil hydrological parameters (Wang and Dickinson 2012) and can be fundamental to understand the soil-plant-atmosphere relationships (Gabarrón-Galeote et al. 2013) that underpin diverse hydrological issues. The spatiotemporal evolution of soil water conditions directly determines various natural 
conditions including the state and composition of vegetation cover, vulnerability to erosion processes, and the stability of soil aggregates (Eskandari Damaneh et al. 2021). This is also fundamental to assess other phenomena including climate change and desertification, which are necessary to develop efficient water resource management plans (Jodar-Abellan et al. 2019a, 2019b).

Recent reports have estimated that the predicted climate change would imply a modification in not only the total amount of rainfall, but also the spatiotemporal distribution patterns (IPCC 2014, 2019). Future climate change projections indicate a trend of decreasing total rainfall and an increase in its intensity and concentration periods (Dore 2005; Pendergrass and Hartmann 2014). Spatial ecosystem responses are variable depending on the specific characteristics of each region, which are conditioned by local factors, and the ability of species to adapt to new climatic conditions (Rahmati et al. 2019). Especially, in the Mediterranean belt, including southern Spain, this issue is becoming more intense (SilleroMedina et al. 2019a, 2019b). Understanding changes in the soil water balance and, therefore, water availability for plants is of great relevance for fragile ecosystems including the Mediterranean one (e.g., Grayson et al. 1997; Llorens et al. 2003; Fernández and Trillo 2005; Katz et al. 2005; Negri et al. 2005; Medrano et al. 2007; De Luis et al. 2011; LemusCanovas and Lopez-Bustins 2016; Olcina-Cantos 2017). In this area, water is the major limiting factor determining the plant production and structure of communities (Ferreras Chasco 2000; Terradas 2001).

The water available for plants can be defined as the amount of water retained into the soil, resulting from the difference between the field capacity (FC) and the permanent wilting point (PWP) (Kirkham 2005). This varies according to soil characteristics such as soil texture and structure (Behnam et al. 2020). Both soil texture and structure affect soil matrix potential linked to the water suction capacity by plants (Givi et al. 2004; Martínez-Fernández 1996). This is directly modified by the potential evapotranspiration (Campos et al. 2013). In arid and semiarid environments, large differences in soil AWC occur because of fluctuating water balances and ongoing changes between water revenues and demand (Dong et al. 2019; Gomes Marques et al. 2019). The open vegetation pattern in the Mediterranean results in only part of the excess water being stored in the root zone and depending on its depth; plants can use it during deficit periods, while the rest drains to deeper layers (Joffre and Rambal 1993). Campos et al. (2016) reported that areas registering diverse soil moisture conditions differed according to their degradation states and inclination. These differences favor a greater plant cover in climatic environments ranging from subhumid to dry. As aridity increases, the pattern of moisture in the soil profile becomes more uniform. This results in less significant changes in vegetation, which uses to be better adapted to lower water availability (Ruiz Sinoga et al. 2011).
Under Mediterranean conditions, when soil moisture is high and soil moisture content is sufficient to support plant physiological processes (Laio et al. 2001), soil transpiration rate depends on the vegetation pattern itself and climatic conditions (Campos et al. 2016). However, below this moisture point, plants start to reduce transpiration to avoid internal water loss (Gabarrón-Galeote et al. 2013). Below that point, soil water availability becomes a key factor determining the current evapotranspiration, which continues at a reduced rate until soil moisture reaches the PWP. These points depend on the type of vegetation and soil characteristics and are generally determined in terms of the soil matrix potential for volumetric water content (Gabarrón-Galeote et al. 2013; Laio et al. 2001; Larcher 1995).

The FC refers to the amount of water retained into the soil when excess water has drained away, and downward flow has ceased being usable by vegetation (Ruiz Sinoga et al. 2011). Consequently, the PWP can be defined as the moisture content of the soil in the root zone at which a withered plant cannot recover turgidity, even if it is in a saturated atmosphere for $12 \mathrm{~h}$ (Ruiz Sinoga et al. 2011; Campos et al. 2016). The relationship existing in a given soil between the moisture content at PWP and the one it possesses in FC is known as AWC (Martínez-Fernández 1996). However, there is currently no information about the number of consecutive days those Mediterranean soils are subject to a soil moisture content below the PWP (soil driest period), especially in southern Spain. In this study, rainfall data, field measurements using soil moisture probes (TDR), and laboratory simulations of soil wetting/ drying to relate the number of days without precipitation to the hydrological state of the soil were estimated. We hypothesize that our results should aid the development of land management plans and predictions of the negative impacts of climate change on Mediterranean ecosystems. Understanding the soil AWC, as well as its dynamic in recent years, will represent a step forward in analyzing the possible impacts of these impacts on the phenology of the vegetation.

\section{Materials and methods}

\section{Study area}

The study area is located in a representative hotspot along with southern Spain (Fig. 1). This area is situated along the Littoral Betic Range, where over just $308 \mathrm{~km}$ of differences in pluviometry gradient occurs from $1400 \mathrm{~mm}$ per year in the Sierra de Grazalema (Cadiz) to $150 \mathrm{~mm}$ per year in Cabo de Gata (Almeria). This gradient reflects a climatic variability that oscillates between a humid Mediterranean climate in the western part and aridity in the eastern one. Therefore, some authors hypothesized that this gradient would have direct 

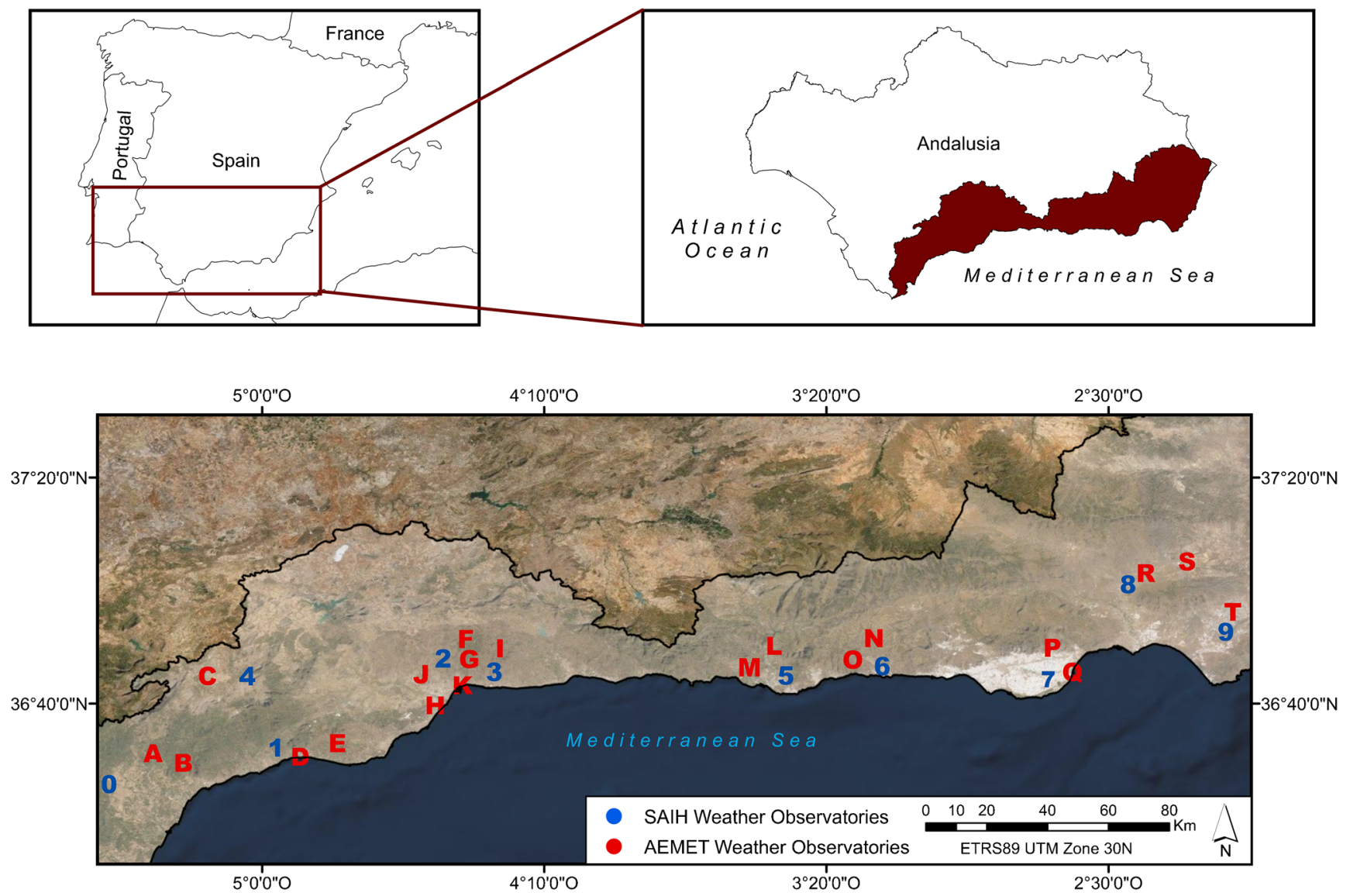

Fig. 1 Study area

impacts on the landscape, ecosystems, and geomorphological processes (Ruiz-Sinoga and Romero Diaz 2010).

\section{Rainfall monitoring data and assessment}

Data from ten climate observatories of the Spanish State Meteorological Agency (AEMET) located along some points in southern Spain were used. Our analysis was divided into four different areas from the West to East, due to their different climatic conditions: (i) the western area (W), with a humid Mediterranean climate (> $700 \mathrm{~mm} /$ year); (ii) Málaga (M) and Costa Granadina $(\mathrm{G})$, with dry conditions $(400-700 \mathrm{~mm} /$ year); and (iii) the eastern area (E) with semi-arid and arid characteristics $(<400 \mathrm{~mm} /$ year $)$.

The daily precipitation database was obtained from AEMET (Table 1; Fig. 1) and allowed us to analyze the following parameters: rainfall on rainy days, the daily maximum rainfall, the number of consecutive days without rain, dry periods, and the maximum number of consecutive days without precipitation (duration of the dry period).

Hourly rainfall data obtained from the Automatic Hydrological Information System (SAIH) network for the Andalusian Mediterranean Basins (Table 2; Fig. 1) for the period (1997-2019) were used to assess climate variations associated with the soil moisture conditions (1997-2019). Hourly events able to reach rainfall amounts higher than the infiltration rates were selected to determine how much rain was not infiltrated. Finally, evapotranspiration data (Table 3) from the Institute for Agricultural and Fisheries Research and Training (IFAPA) for the same period (1997-2019) was also analyzed.

The databases were integrated chronologically for the four zones along the pluviometry gradient. This involved a database of daily precipitation covering at least 50 years, a 22 -year hourly precipitation database, and a database of soil moisture at a depth of $50 \mathrm{~cm}$ for the last 22 years. For the 25 representative sites, the soil moisture corresponding to the two basic hydrological states (PWP and FC) was also included.

\section{Soil hydrological conditions and laboratory analysis}

A total of 543 soil samples were collected in spring 2008 and 2009 analyzed for 25 representative sites. Thus, 112 samples belonging to the Mediterranean humid area, 99 to the subhumid part, 118 to the dry territories, 102 to the semi-arid points, and 112 to the arid climate locations were collected. All of them belong to areas with metamorphic lithology (phyllites, schist), similar hillslope inclinations (between 10 
Table 1 Selected AEMET weather observatories used in the study. Abbreviations: W, western area; M, Málaga; G, Granada coast; E, eastern area

\begin{tabular}{lllll}
\hline AEMET code & Station name & Coordinates XY ETRS89 UTM Zone 30N & Altitude $(\mathrm{m})$ & Area \\
\hline $1-43$ & Gaucín & $292081-4044073$ & 630 & $\mathrm{~W}$ \\
$1-44$ & Genalguacil & $300017-4040747$ & 534 & $\mathrm{~W}$ \\
$2-72$ & Ronda & $307023-4069091$ & 743 & $\mathrm{~W}$ \\
$3-55$ & Marbella & $330975-4042108$ & 16 & $\mathrm{~W}$ \\
$3-56$ & Marbella2 & $330887-4042799$ & 59 & $\mathrm{~W}$ \\
$4-64$ & Pantano Agujero & $372123-4070772$ & 117 & $\mathrm{M}$ \\
$4-49$ & Boticario & $376124-4073244$ & 576 & $\mathrm{M}$ \\
$5-48$ & Aeropuerto Malaga & $366937-4058334$ & 24 & $\mathrm{M}$ \\
$5-50$ & Contadoras & $376458-4076289$ & 760 & $\mathrm{M}$ \\
$5-51$ & Málaga Ejido & $373351-4065628$ & 40 & $\mathrm{M}$ \\
$5-52$ & Málaga Oficina & $374207-4064799$ & 10 & $\mathrm{M}$ \\
$6-226$ & Motril & $453724-4070052$ & 29 & $\mathrm{G}$ \\
$6-227$ & Motril. Club náutico & $452887-4064467$ & 4 & $\mathrm{G}$ \\
$7-96$ & Albuñol & $481947-4071845$ & 200 & $\mathrm{G}$ \\
$7-97$ & Albuñol a Órgiva & $481558-4074080$ & 685 & $\mathrm{G}$ \\
$8-259$ & Roquetas Pueblo & $534364-4068719$ & 9 & $\mathrm{E}$ \\
$8-260$ & Roquetas Faro & $535100-4068001$ & 3 & $\mathrm{E}$ \\
$9-265$ & Tabernas & $554239-4100777$ & 408 & $\mathrm{E}$ \\
$9-266$ & Tabernas a Sorbas & $565062-4104645$ & 561 & $\mathrm{E}$ \\
$10-231$ & Níjar & $577232-4088198$ & 140 & $\mathrm{E}$ \\
\hline & & & &
\end{tabular}

and $16 \%$ ), and vegetation cover degree and typology. After sampling (disturbed and non-ones cores), we analyzed the percentage of vegetation cover, the number of species in the surroundings of the sample $\left(100 \mathrm{~m}^{2}\right)$, bulk density (BD), soil texture, organic matter (OM), organic carbon (OC), structural stability (AS), permeability, as well as FC and PWP (Table 4). Moreover, both humidification and drying tests under laboratory conditions and using in situ tests through TDR (time domain reflectometry) humidity sensors during the periods 2002-2006 (Hydrosur Project), 2006-2010 (Hydrosur2 Project), 2010-2014 (REME Project), and 2016-2019 (GLOMEDLAND Project) were used following the protocols described by Ruiz-Sinoga and Romero Diaz (2010).

\section{Statistical analysis}

Based on environmental, pedological, and climatic data, a principal component analysis (PCA) was carried out to determine those factors that allow to explain the soil hydrological dynamics along with southern Spain. Thus, these data have been normalized into five different categories depending on the variable, either from the lowest to the highest values or from the oldest to the newest ones. This analysis was performed using SPSS version 25 (IBM Corp 2017, USA; corporate license of the University of Malaga). The variables used were annual rainfall ( $\mathrm{mm}$ ), vegetation biodiversity (number of species) (VB), available water (days) (AW), rainy days,
Table 2 Selected weather observatories in the $\mathrm{SAIH}$ network. Abbreviations: W, western area; M, Málaga; G, Grenadine coast; E, eastern area

\begin{tabular}{lllll}
\hline $\begin{array}{l}\text { SAIH Hydrosur } \\
\text { Network Code }\end{array}$ & Station name & $\begin{array}{l}\text { Coordinates XY ETRS89 } \\
\text { UTM Zone 30N }\end{array}$ & Altitude (m) & Area \\
\hline 9 & Hozgarganta & $280189-4034238$ & 37 & $\mathrm{~W}$ \\
16 & Concepción & $324643-4045234$ & 110 & $\mathrm{~W}$ \\
20 & Limonero & $372436-4069267$ & 136 & $\mathrm{M}$ \\
22 & Málaga & $374218-4064810$ & 24 & $\mathrm{M}$ \\
27 & Ronda & $306584-4069318$ & 770 & $\mathrm{~W}$ \\
60 & Motril & $453614-4067322$ & 69 & $\mathrm{G}$ \\
72 & Albuñol & $484959-4070128$ & 414 & $\mathrm{G}$ \\
78 & Punta Sabinar & $526616-4060200$ & 9 & $\mathrm{E}$ \\
93 & Rambla de Tabernas & $549623-4097053$ & 264 & $\mathrm{E}$ \\
97 & Níjar & $575436-4081658$ & 231 & $\mathrm{E}$ \\
\hline
\end{tabular}


Table 3 Selected weather observatories in the IFAPA network https://www. juntadeandalucia.es/ agriculturaypesca/ifapa/riaweb/ web/estaciones. Abbreviations: W, western area; M, Málaga; G, Grenadine coast; E, eastern area

\begin{tabular}{llll}
\hline Station name & Coordinates XY ETRS89 UTM Zone 30N & Altitude $(\mathrm{m})$ & Area \\
\hline Jimena & $286263-4032470$ & 50 & $\mathrm{~W}$ \\
Estepona & $301937-4035540$ & 185 & $\mathrm{~W}$ \\
Churriana & $365680-4059740$ & 17 & $\mathrm{M}$ \\
Campanillas & $360629-4065960$ & 63 & $\mathrm{M}$ \\
Pizarra & $346918-4070360$ & 71 & $\mathrm{M}$ \\
Cártama & $350119-4064780$ & 78 & $\mathrm{M}$ \\
Almuchécar & $439384-4067570$ & 29 & $\mathrm{G}$ \\
Cádiar & $483613-4086360$ & 928 & $\mathrm{G}$ \\
Adra & $500683-4066780$ & 2 & $\mathrm{E}$ \\
Almería & $553282-4076780$ & 5 & $\mathrm{E}$ \\
Tabernas & $561998-4105230$ & 502 & $\mathrm{E}$ \\
Níjar & $577785-4089250$ & 158 & $\mathrm{E}$ \\
\hline
\end{tabular}

OM (\%), OC (\%), rainfall summation of 50 days before the dry season $(\mathrm{mm})$, rainfall summation of 10 days after the dry season $(\mathrm{mm})$, vegetation cover, $\mathrm{AS}, \mathrm{BD}$, sand (\%), silt (\%), clay $(\%)$, hydraulic conductivity, heavy rainfall (HR) $(\%)$, available water continuous period (days), evapotranspiration, slope (\%), field capacity period (days) (FC), wilting point period (days) (WP), xeric period (XP) (days), and driest year (days). In addition, factor analysis was performed using the covariance (raw data) and the correlation matrix (standardized data). Using a correlation matrix, factors with eigenvalues $>1$ were retained and subjected to varimax rotation to maximize the correlations among factors (Shukla et al. 2006). Finally, Bartlett's test and the KMO (Kaiser-Meyer-Olkin) test were applied.

\section{Results and discussion}

\section{Rainfall patterns}

Analysis of the AEMET database (1959-2019) showed changes in the daily rainfall distribution over time in southern Spain (Figs. 2 and 3). This included a progressive reduction in the number of rainy days, which is consistent with other reports for other arid and semiarid regions of the world (Dore
2005; Pendergrass and Hartmann 2014). Similarly, the average number of consecutive days without rain also decreased (from almost 6 to 5.3 days). Therefore, the number of rainy days hardly changed, even the maximum number of days without rain increased; however, the duration of the XP did increase. Thus, the length of the dry season increased, which is also consistent with other recent studies in Australia and China among others (Guo et al. 2019; He et al. 2017; Rahmati et al. 2019).

The reduction in rainy days was assessed in the context of changes in the rainfall pattern. The historical AEMET database showed this progressive change, evident as a reduction in the average rainfall for each rainy day (from 12 to $8.8 \mathrm{~mm}$ ) (Fig. 4). Thus, there was a considerable increase in the maximum daily rainfall amount (from 88 to $110 \mathrm{~mm}$ ), probably because of more intense precipitation, as reported for all of Spain by Martin Vide (2004).

\section{Hydrological dynamics of the soil surface}

Figure 5 shows that during summer, soils were conditioned by the effects of summer droughts and registered the minimum humidity values. Consequently, this coincides with a stressful period for plants, as also reported by Jordano et al. (2002).
Table 4 General characteristics of the study areas. Abbreviations: SD, soil depth $(\mathrm{cm})$; $\mathrm{BD}$, bulk density $\left(\mathrm{g} / \mathrm{cm}^{3}\right)$; OM, organic matter $(\%)$; OC, organic carbon $(\%)$; AS, structural stability $(\%)$; Ksat, permeability $(\mathrm{cm} /$ $\mathrm{h}$ ); VB, vegetation biodiversity (number of species); VC, vegetation cover (\%); SM Max, soil moisture maximum value (\%); SM Min, soil moisture minimum value (\%); SM, soil moisture (\%); WP, wilting point $(\%)$; FC, field capacity $(\%)$

\begin{tabular}{|c|c|c|c|c|c|c|c|c|c|c|c|c|c|c|c|c|c|c|}
\hline & $S D$ & $B D$ & Porosity & $\begin{array}{l}\text { Very fine } \\
\text { sand }\end{array}$ & Sand & Silt & Clay & $O M$ & $O C$ & $A S$ & Ksat & $V B$ & $V C$ & $\begin{array}{l}S M \\
\operatorname{Max}\end{array}$ & $\begin{array}{l}\text { SM } \\
\text { Min }\end{array}$ & $S M$ & $W P$ & $F C$ \\
\hline Weste & 69.00 & 1.20 & 48.8 & 12.36 & 38.18 & 34.87 & 23.36 & 7.74 & 28.10 & 74.53 & 17.57 & 8.50 & 81.64 & 35.27 & 2.45 & 19.86 & 12.00 & 32.00 \\
\hline Málaga & 56.00 & 1.30 & 46.6 & 17.34 & 31.64 & 35.05 & 24.65 & 3.97 & 13.83 & 72.55 & 10.22 & 7.22 & 57.22 & 24.80 & 1.86 & 12.63 & 7.10 & 18.20 \\
\hline Grenadine Coast & 38.00 & 1.38 & 44.3 & 25.23 & 57.82 & 28.53 & 12.94 & 2.03 & 7.71 & 62.27 & 6.84 & 4.20 & 44.60 & 17.65 & 1.42 & 8.66 & 3.60 & 18.00 \\
\hline Eastern area & 23.00 & 1.44 & 43.7 & 13.77 & 54.18 & 30.73 & 15.09 & 1.61 & 6.42 & 59.23 & 5.08 & 2.00 & 40.00 & 8.50 & 1.18 & 5.05 & 2.50 & 18.10 \\
\hline
\end{tabular}




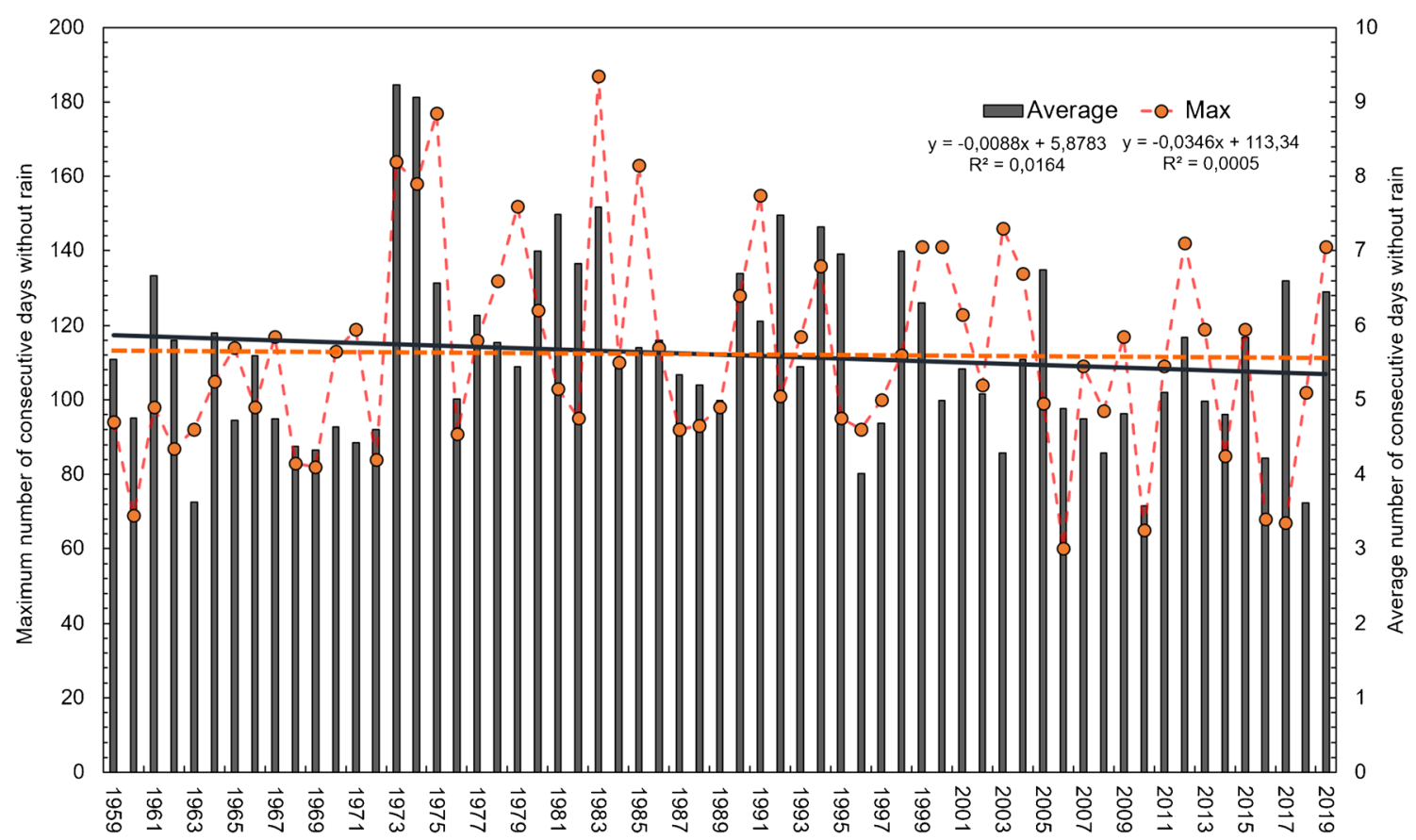

Fig. 2 Analysis of the AEMET database (1959-2019)

This situation, which occurred almost every year, indicates that the soil water available for vegetation was low (Martínez-Fernández et al. 2001; Cortesi et al. 2012). In contrast, during spring and autumn, optimum soil moisture values were reached for the use of plants, sometimes exceeding the content that determines the FC.

Our results confirm that there were extreme weather situations conditioning ASWC. It is appreciated that there was a large number of drought periods and, by contrast, sporadic and random occurrences of heavy rainfall events (Martínez-Fernández et al. 2001; Cortesi et al. 2014; Martin-Vide and Lopez-Bustins 2006). In short, there was marked seasonal variability in the soil moisture conditions (Gallart et al. 2002), as was evident in the data from most of the weather stations analyzed (Fig. 5). At the Hozgarganta station, in particular, the FC state was exceeded on a large number of days. The same was evident at the Malaga City weather station, where this state was reached at lower humidity values (\%), which, considering the recent publication by Senciales-González et al. (2020), could even generate heat islands at the urban scale.

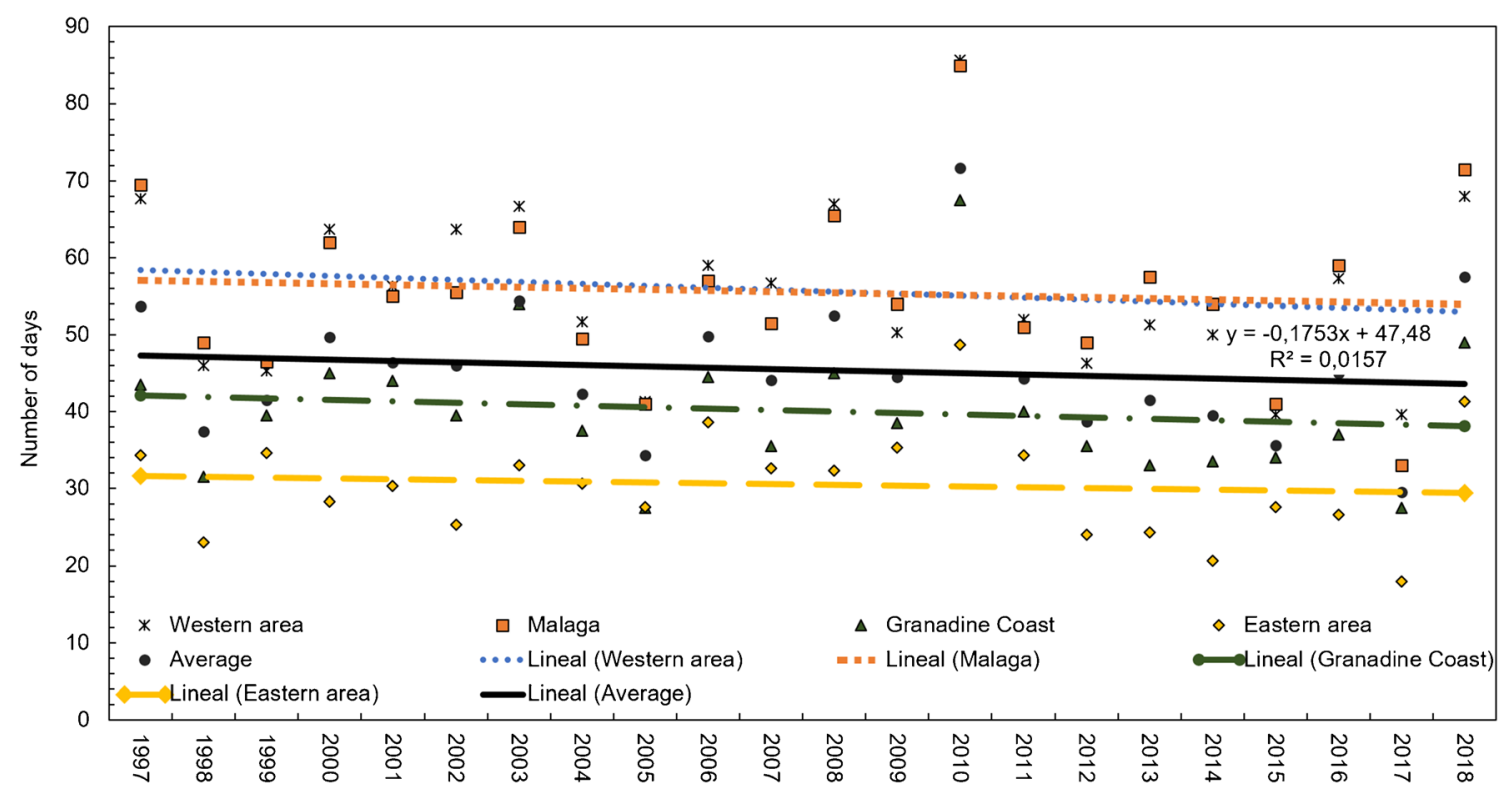

Fig. 3 Number of days of rainfall distribution 


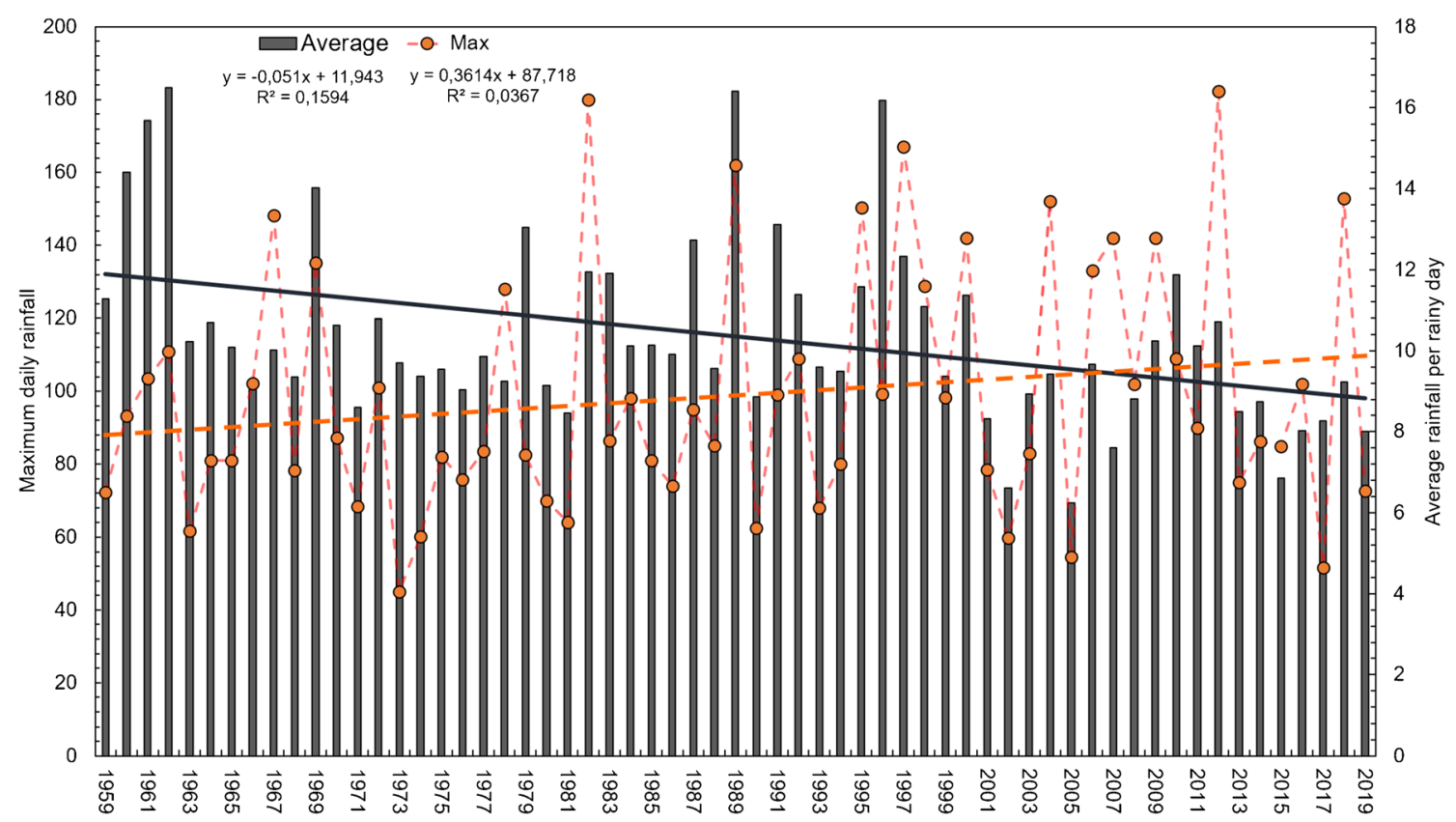

Fig. 4 The historical AEMET database

Along the pluviometry gradient considered in this study, the periods during which the soil was below the PWP occurred much more frequently and for a longer duration in the more arid eastern sector (E) of the Mediterranean basin. Thus, sampling sites including Albuñol (Granada province) or Tabernas (Almería province) reached an optimum state of soil moisture (useful reserve) on few occasions and very irregularly, resulting in frequent occurrences of water stress throughout the year.

Figure 5 also shows in each selected zone the medium values of the interannual pluviometry variability. The hydrological state of the soil showed an elevated spatiotemporal variability, which depended on several factors. In terms of the potential AWC, in the westernmost zone (W), the wettest soils registered values of $12 \%$ for the PWP and $32 \%$ for the $\mathrm{FC}$, while in the easternmost (E) area, those parameters had values of $3 \%$ and $18 \%$, respectively. However, as the aridity conditions increased, the number of days on which the soil was above the FC declined, because of several consecutive days of precipitation. The number of consecutive days on which the ground was below the PWP also increased.

Based on this interannual perspective and the variability patterns, the number of days without rain increased at all climate observatories, except those in the western (W) zone (Fig. 6). In general terms, the number of days on which the soil hydrological state was below the PWP increased for most of the observatories (in $\mathrm{W}$ and $\mathrm{M}$ increased in more than 10 days), except in the oriental ones, where was slightly reduced (Fig. 7). The stations were grouped considering the number of days without rain and soil moisture.
These general approaches did not consider that at some observatories the magnitude of the soil driest periods could be interpreted as extreme. The largest increase in the number of days in the soil driest period corresponded to the eastern (E) observatories, where in several years in the last decade, this period has extended well beyond 200 days; for example, in 2016, there were 338 days at Nijar station during which the soil was below the PWP, and in 2019, it was up to 256 days. They have practically been found all year round in what could be known as the "driest period" (Table 5).

Thus, as other scholars have previously demonstrated (e.g., Grayson et al. 1997; Llorens et al. 2003; Fernández and Trillo 2005; Katz et al. 2005; Negri et al. 2005; Medrano et al. 2007; De Luis et al. 2011; Lemus-Canovas and Lopez-Bustins 2016; Olcina-Cantos 2017), the Mediterranean is a fragile ecosystem in which water is the most important limiting factor for plant production (Ferreras Chasco 2000; Terradas 2001) and a major determinant of the configuration of plant communities (Sillero-Medina at al. 2019). If this trend continues in the number of days without rain and on which the soil is in water deficit, the repercussions for the ecosystem will be severe, especially regarding the water availability for plants (Dunkerley 2002; Martínez-Fernández et al. 2001).

\section{Rainfall pattern impacts on soil hydrological conditions}

In the context of climate change, rainfall in the Mediterranean area is expected to become more concentrated, and extreme rainfall will increase (IPCC 2014). Under these conditions, the 


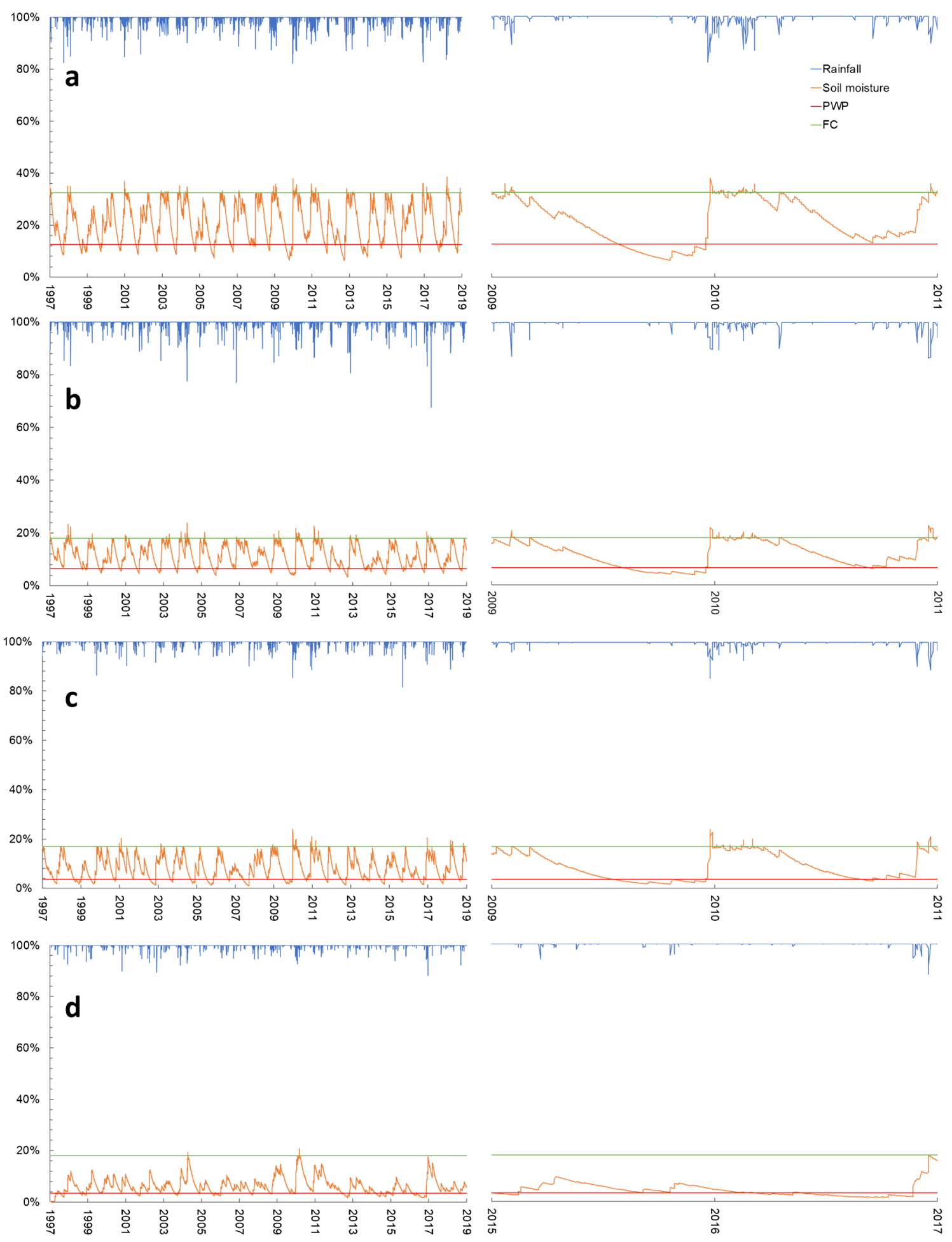

Fig. 5 Marked seasonal variability in the soil moisture conditions

infiltration rate of a given soil may be exceeded with greater frequency (Fig. 8), and when precipitation exceeds the infiltration rate of the soil, runoff is generated (Cerdà et al. 2021a; Imeson and Lavee 1998). The poor development of soils, resulting from intense erosion processes, and the proximity of the topsoil to the parent material, also exacerbates rapid soil saturation and consequently surface runoff in the case of continuing precipitation (Cerdàet al. 2021b; Panagos et al. 2014). Thus, changes in rainfall patterns can directly affect the hydrodynamics of surface formations and the retention of water by soil, as manifested through its moisture content. 


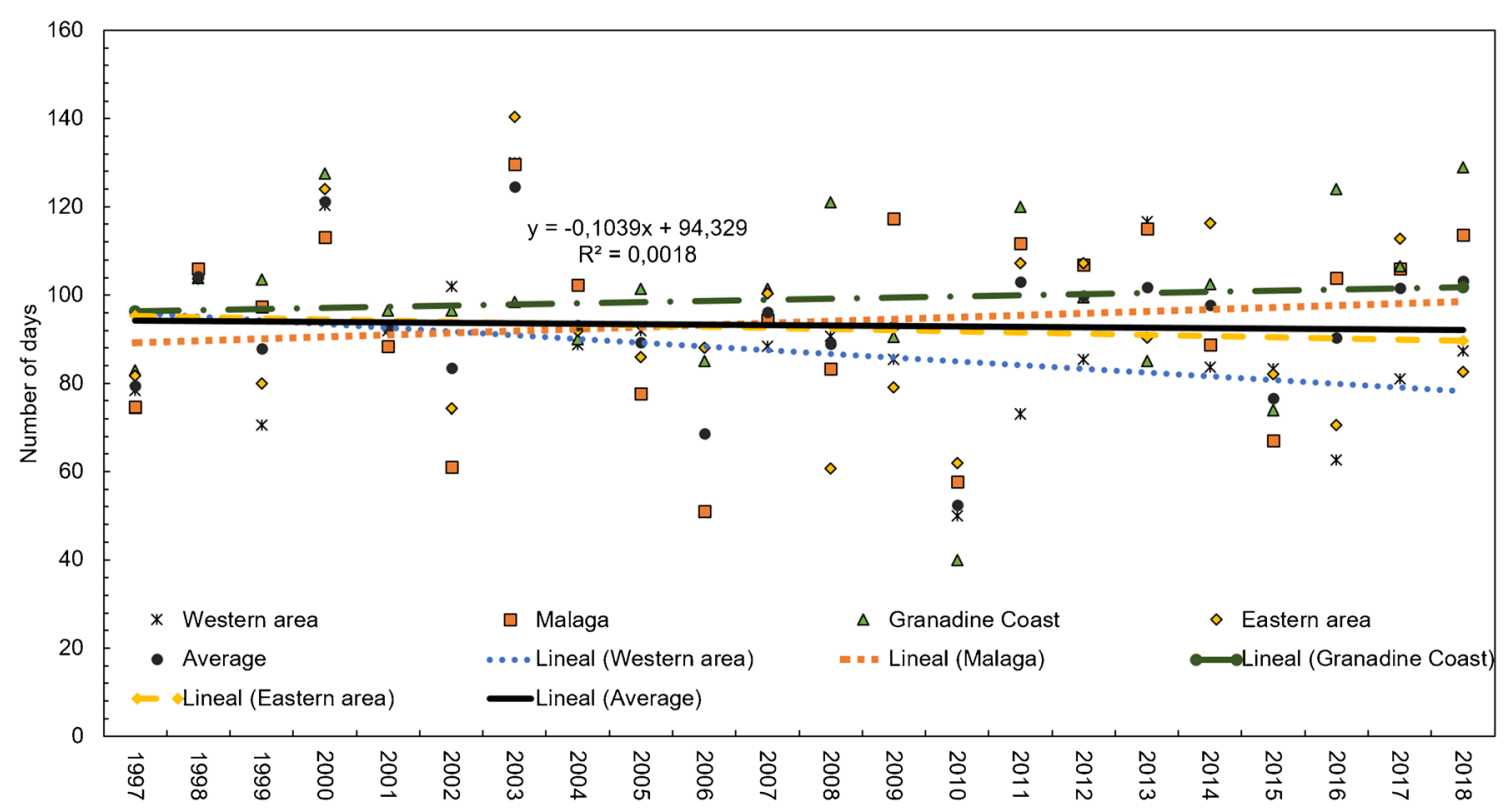

Fig. 6 The number of days without rain increased at all climate observatories

For the study period, it has been defined a rainfall pattern, with a direct incidence from soil hydrology. At those observatories corresponding to a humid-subhumid Mediterranean climate, a slight decrease in rainfall was recorded, net precipitation increased, or precipitation exceeded the soil infiltration rate. Thus, more than $40 \%$ of rainfall generated runoff, indicating much of the rainfall infiltrated into the soil; this is especially significant, considering the absolute values (MartinVide 2004; Cortesi et al. 2012; Ruiz-Sinoga et al. 2010a). At those observatories corresponding to a dry Mediterranean climate, a slight reduction in rainfall and an increase in excess rainfall was also observed, but the levels were lower than in the humid-subhumid zone, and approximately $50 \%$ of the precipitation infiltrated into the soil.

At the observatories in semiarid and arid areas, the pattern was different. With average annual records showing less than $300 \mathrm{~mm}$ rainfall in semiarid conditions and $150 \mathrm{~mm}$ in arid zones, the precipitation slightly increased. The variations of scarce water resources can also show even other different patterns depending on how soils are managed when the precipitation rate exceeds the soil infiltration rates. Rodrigo-Comino et al. (2019) demonstrated this in poorly managed abandoned plots

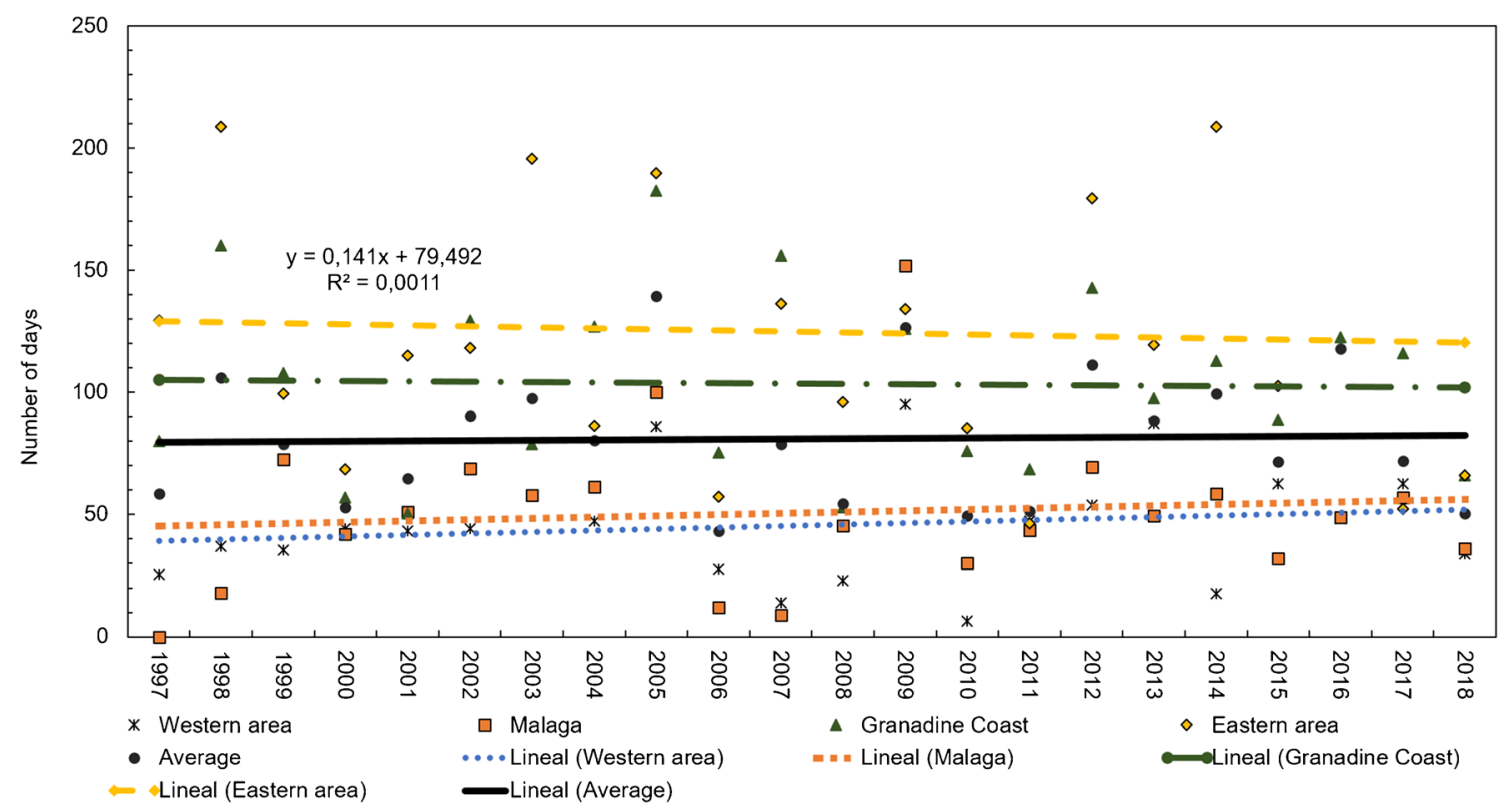

Fig. 7 The number of days on which the soil hydrological state was below the PWP increased for most of the observatories 


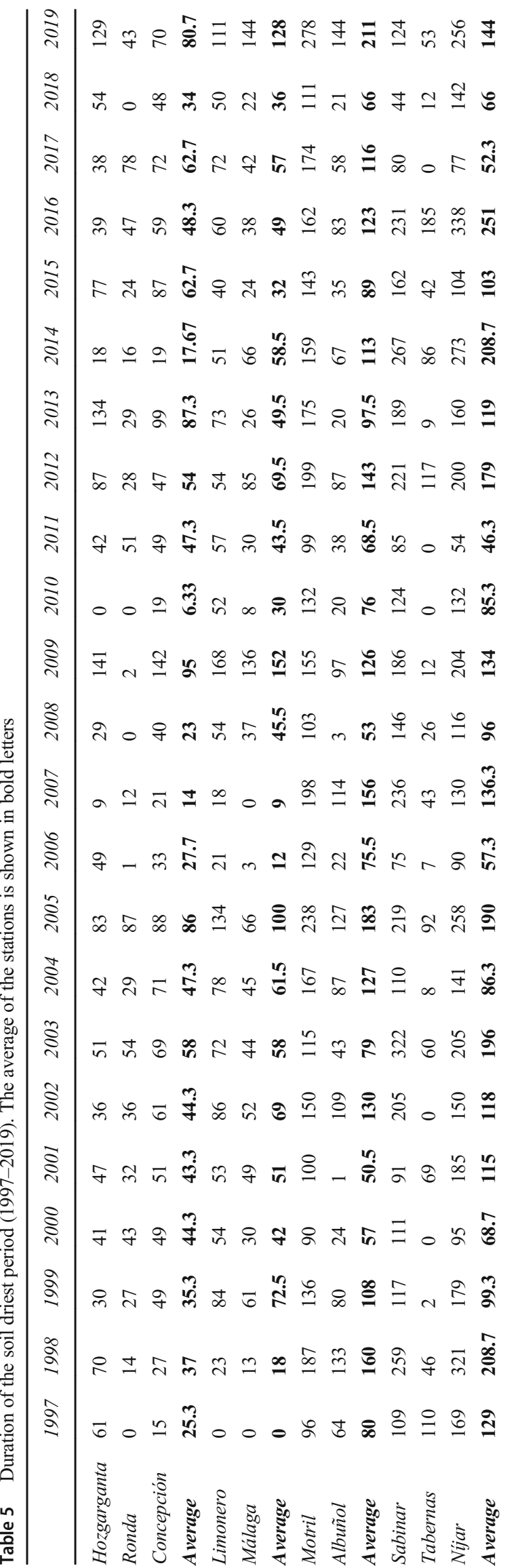

previously cultivated with vineyards in southern Spain. Therefore, the obtained results could also vary in several magnitudes considering human impacts.

\section{Incidence of the rainfall gradient in determining factors of the soil hydrological dynamics}

The results corresponding to the general hydrodynamics in the mentioned pluviometric gradient are consistent since they have been corroborated by principal component analysis $($ KMO test $=0.864$; Bartlett's sphericity $=0.000)($ Table 6$)$.

For the considered pluviometry gradient, the results show the importance of the factors related to water and its consequences, mainly in the organic factors and in the properties of the soil, in the same line that has already been raised by other experts (Imeson and Lavee 1998; Cerdà 1998; Novara et al. 2014; Asgari et al. 2020). Thus, following the PCA results (Tables 7 and 8), five different components (C) are able to explain $85.9 \%$ of the total variance. Especially, it is significant that up to three components can explain $69.7 \%$. C1 $(29.5 \%$ of the variance) is related to the organic component, grouping the rainiest areas, not only with higher biodiversity and vegetation density, but also with a higher content of organic matter and organic carbon sequestration. These results agree with other recent studies that highlight the relevance of precipitation and increase in organic matter and, subsequently, in vegetation cover, although human activities (agriculture, urbanization, etc.) highly modify this trend (Lado et al. 2004; Ruiz-Sinoga and Romero Diaz 2010; Ruiz-Sinoga et al. 2010b; Ruiz Sinoga et al. 2011; Sillero-Medina et al. 2019b; Desjardins et al. 2020; Ayoubi et al. 2020).

$\mathrm{C} 2$ (27.3\% of the variance) is directly related to the pedological properties. The most stable soils are those that register higher BD, sand, and silt percentages, showing a higher infiltration capacity (Shukla et al. 2006; Al-Shammary et al. 2020). C3 reaching a $12.8 \%$ of the whole variance is related to the torrentiality of the rain, grouping higher percentages of heavy rainfall, rainfall summation of 10 days after the dry season (mm) and evapotranspiration (Boegh et al. 2002; Bosch and Hewlett 1982; Domingo et al. 1999). However, torrential rainfall not only is important in the management of water resources by vegetation but also has a direct effect on landscape modelling (Angulo-Martínez et al. 2009; Negese et al. 2021). In addition, it is inversely related to the duration of the continuous period of AW and slope percentage. C4 ( $8.9 \%$ of the variance) grouped the years with a longer duration of XP; a higher number of days with soils below WP are the last in the series. Furthermore, this component is inversely related to the period in FC. Finally, clay explains $7.2 \%$ of the variance and appears as an isolated factor. 

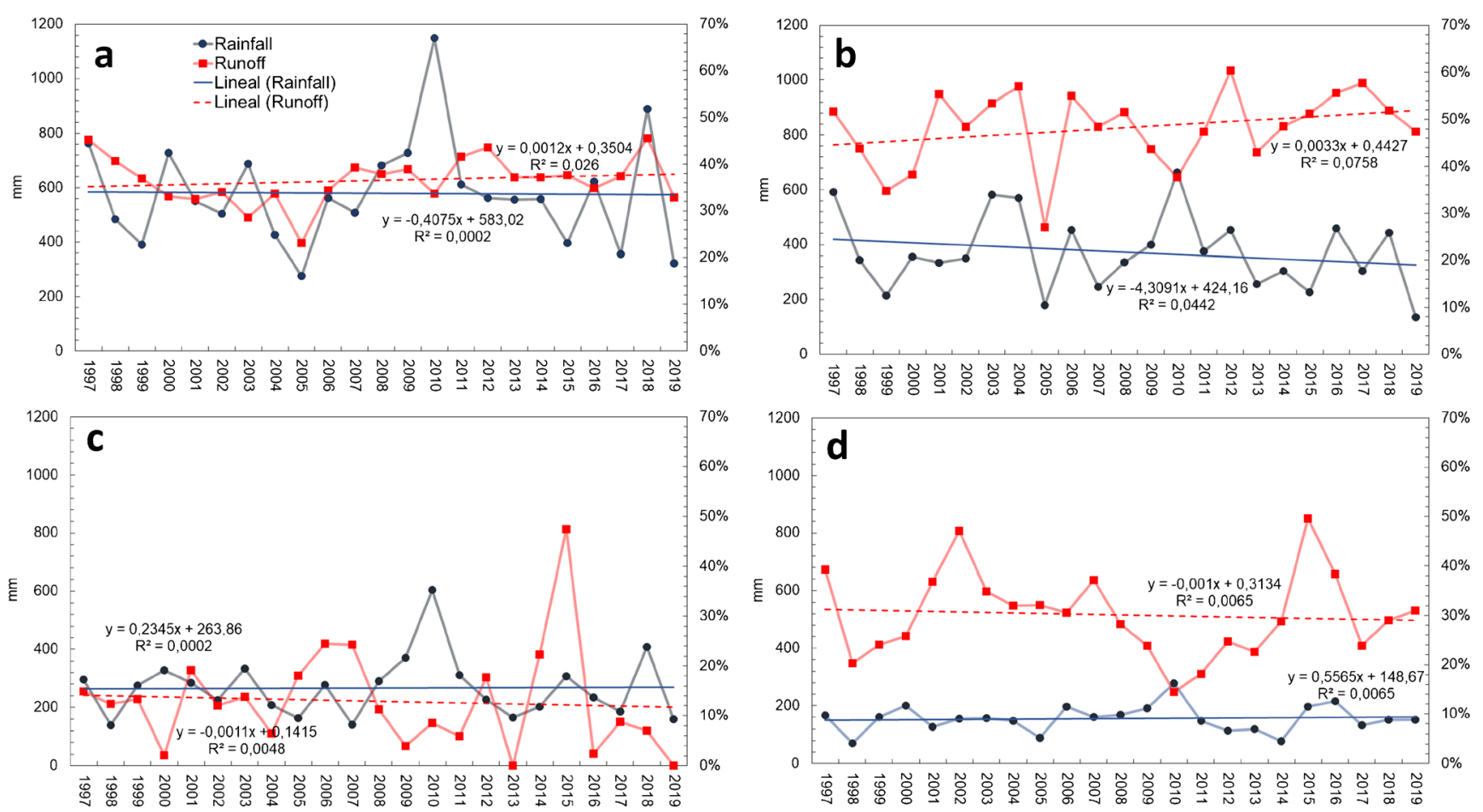

Fig. 8 The infiltration rate of a given soil

\section{Humid areas (W) (> $700 \mathrm{~mm} /$ year)}

In humid areas, the PCA has shown both a KMO and Bartlett's test with adequate values (Table 6), with six components that explain $75 \%$ of the variance, of which the first one explains $34 \%$ of it (Table 7). Thus, in these humid areas, the factors associated with water management explain most of the variance, grouping stable soils with high organic matter content (56.3\% of the variance), in line with other studies (Laio et al. 2001; Shukla et al. 2006; Ruiz-Sinoga and Romero Diaz 2010; Pulido-Fernández et al. 2013; Novara et al. 2014). C1 (Table 9) is associated with hydrological variables (34.3\% of the variance), with the AW. The areas with the highest rainfall are those with the longest AW period, even continuous (AWc), where maximum rainfall occurs in spring and where the highest values of $\mathrm{VC}$, $\mathrm{VB}$, and permeability are found. Thus, in these areas, the most recent years are the driest.

$\mathrm{C} 2$, with $12.4 \%$ of the variance, is related to the soil texture. The highest values of clay and silt contents correspond to the

lowest values of FC. C3 explains $9.6 \%$ of the variance and it is related to the organic factor. The most structurally stable soils, i.e., with higher AS, correspond to higher OM and OC contents. $\mathrm{C} 4$ ( $7.1 \%$ of the variance) could be considered as a climate factor, since it links the torrential rainfall (HR) inversely to the duration of the XP and the percentage of sand, in relation to that identified by Sillero-Medina et al. (2019a, $2019 b)$. C5, with $6.4 \%$ of the variance, is associated with topographical variables. The areas where the longest periods of WP are reached are those with the steepest slopes.

\section{Dry areas (M and G) (400-700 mm/year)}

In these areas, both the KMO and the Bartlett test have adequate values, which show a statistical significance (Table 6). Six components explain $85.5 \%$ of the variance, from which three explain $61.8 \%$ (Table 7). Thus, in these dry areas, biology, soil stability, and climate variables are the factors that explain this $61.8 \%$ of the variance. These areas act as a threshold between biotic and abiotic factors as controllers of soil

Table 6 Bartlett and the KMO (Kaiser-Meyer-Olkin) tests

\begin{tabular}{llllll}
\hline & & Total & $>700 \mathrm{~mm}$ & $700-400 \mathrm{~mm}$ & $<400 \mathrm{~mm}$ \\
\hline KMO and Bartlett's test & & 0.808 & 0.748 & 0.590 & 0.785 \\
Bartlett's test of sphericity & Aprox. chi-square & 4.154 .953 & 1.405 .681 & 665.801 & 781.251 \\
& $d f$ & 245 & 173 & 175 & 175 \\
& Sig. & 0.000 & 0.000 & 0.000 & 0.000 \\
\hline
\end{tabular}




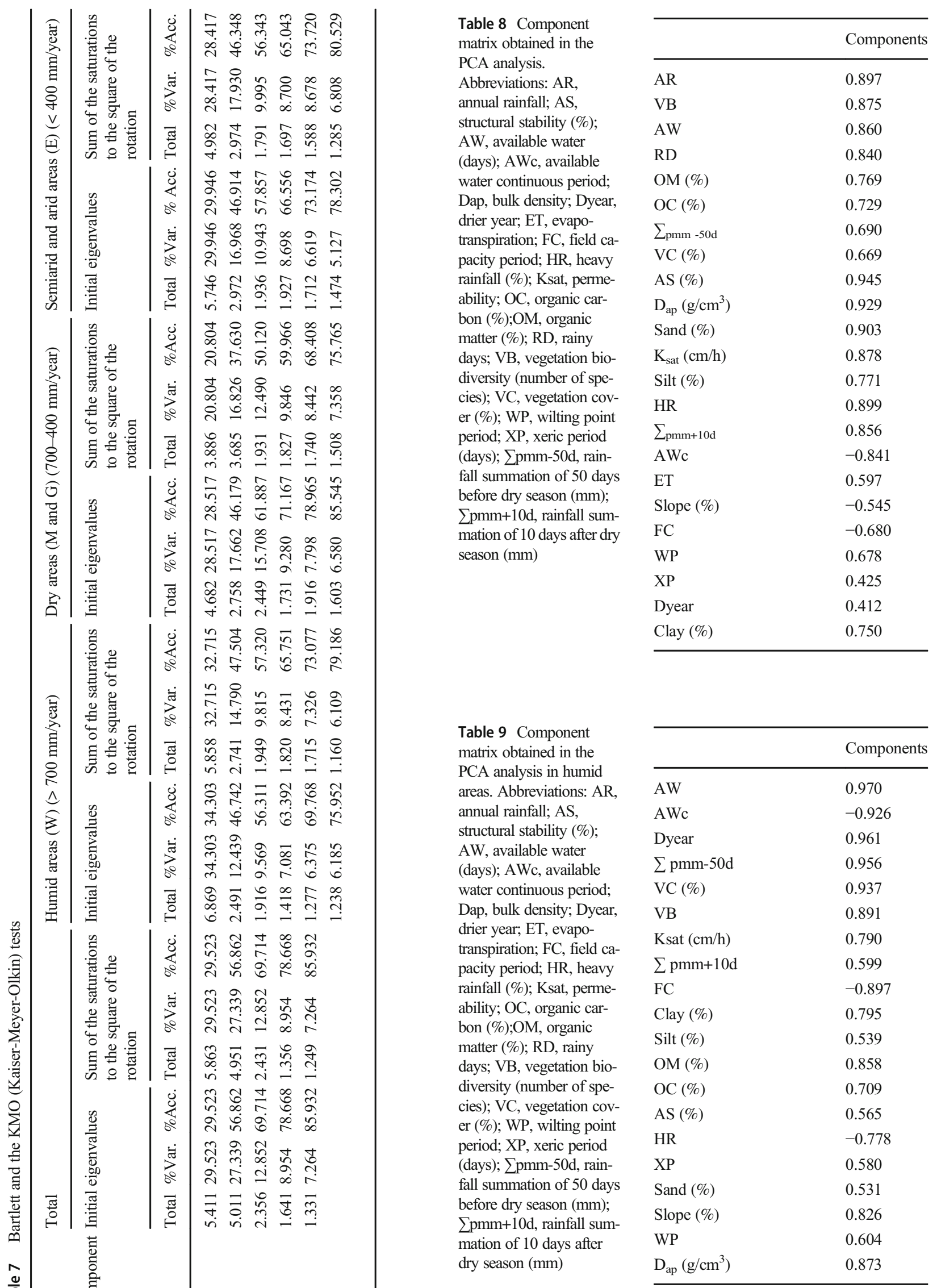


degradation processes, as demonstrated by other authors under similar conditions (Mohammed et al. 2020; Cerdà et al. 2021b).

C1 explains $28.5 \%$ of the variance and can be considered as a biological component. The higher $\mathrm{AW}$ content is related to a higher VC, VB, OM, and OC (Table 10). C2 (17.6\% of the variance) is associated with soil stability. Thus, soils with a better AS are associated with a higher sand content (\%), higher BD, and more days in FC. In addition, these variables are negatively related to torrential rainfall (HR).

C3 explains $15.7 \%$ of the variance and is entirely related to climatic variables. This component is linked to rainfall summation of 50 days before occurring dry seasons (mm) and inversely to 10 days of rain after a dry season ( $\mathrm{mm}$ ). So, C4 has a pedological character and explains $9.2 \%$ of the variance. The soils with higher clay or silt contents are those with lower permeability. C5 can also be connected to C3 and is relative to soil hydrology since as XP is extended, the number of days with AW is reduced. Furthermore, it explains $7.7 \%$ of the variance. Finally, C6 is related to physiography, with $6.5 \%$. The areas with steeper slopes coincide with those that have a lower number of days with AW and the higher ones in WP.

\section{Semiarid and arid areas (E) $(<400 \mathrm{~mm} /$ year $)$}

KMO and Bartlett's test also showed significant results (Table 6). Six factors can explain $78.3 \%$ of the variance

Table 10 Component matrix obtained in the PCA analysis in dry areas. Abbreviations: $\mathrm{AR}$, annual rainfall; AS, structural stability (\%); $\mathrm{AW}$, available water (days); AWc, available water continuous period; Dap, bulk density;

Dyear, drier year; ET, evapotranspiration; FC, field capacity period;

$\mathrm{HR}$, heavy rainfall (\%); Ksat, permeability; OC, organic carbon (\%);OM, organic matter (\%); RD, rainy days; $\mathrm{VB}$, vegetation biodiversity (number of species); VC, vegetation cover $(\%)$; $\mathrm{WP}$, wilting point period; XP, xeric period (days); $\sum \mathrm{pmm}-50 \mathrm{~d}$, rainfall summation of 50 days before dry season $(\mathrm{mm}) ; \sum \mathrm{pmm}+10 \mathrm{~d}$, rainfall summation of 10 days after dry season (mm).
Table 11 Component matrix obtained in the PCA analysis in semiarid and arid areas. Abbreviations: AR, annual rainfall; AS, structural stability (\%); AW, available water (days); AWc, available water continuous period; Dap, bulk density; Dyear, drier year; ET, evapotranspiration; FC, field capacity period; $\mathrm{HR}$, heavy rainfall (\%); Ksat, permeability; OC, organic carbon (\%);OM, organic matter (\%); RD, rainy days; $\mathrm{VB}$, vegetation biodiversity (number of species); $\mathrm{VC}$, vegetation cover (\%); WP, wilting point period; XP, xeric period (days); $\sum$ pmm-50d, rainfall summation of 50 days before dry season $(\mathrm{mm}) ; \sum \mathrm{pmm}+10 \mathrm{~d}$, rainfall summation of 10 days after dry season $(\mathrm{mm})$

(Table 7). In this sense, in the arid environments, it is the torrential nature, the orography, and the biological factors that explain, in this order, $69.3 \%$ of the variance. In these environments, AW is linked to rainfall occurring in such a way that the soils can benefit, and not above the soil infiltration rates, as well as in areas where the slope prevents the generation of surface runoff processes, hence the importance of the physiographic factor and specific rainfall events during concentrated seasons ( $\mathrm{Li}$ et al. 2020; Peña-Angulo et al. 2021). C1, with $29.9 \%$ of the variance, could correspond to torrential rainfall, since it relates the percentage of $\mathrm{RH}$ to the rainfall that occurs after the summer, in addition to the clay and silt content of the soils, and the number of days in WP and XP (Table 11).

$\mathrm{C} 2$, with $19.9 \%$ of the variance, is associated with topographical changes. The number of days in AW, the soils with higher AS and BD, and soft slopes are related. $\mathrm{C} 3$ and $\mathrm{C} 4$, with $19.5 \%$ of the variance in total, are related to the biological factor. Thus, increased precipitation before starting the dry season is associated with higher $\mathrm{VC}$ and $\mathrm{VB}$, and these with higher levels of OM and OC. C5 (6.6\% of the variance) is related to soil hydrology since it directly associates soils with a high percentage of sands with higher permeability and inversely with the number of days in FC. C6, with $5.1 \%$ of the variance, is associated with the current climatic dynamics, as it inversely relates the duration of the continuous period of soils with AW, with the most recent years. In other words, at present, the number of continuous days of soils with AW is increasingly lower ( $5.1 \%$ of the variance). 


\section{Conclusions and possible challenges}

Following the objectives set out, there has been an increase in the length of dry periods as a result of a decrease in both the number of rainy days and the number of consecutive days without rain. While there was a reduction in average daily rainfall, there was an increase in maximum rainfall, indicating that the number of events involving extreme rainfall has increased. Therefore, there has been a significant change in the rainfall pattern, with more concentrated rainfall. Soils reflect the climatic seasonality through their hydrological state. Thus, in summer and early autumn, the humidity was low, with a general tendency to increase in the number of days in which the soil is water-deficient or has a humidity state below the WP. This is of particular significance when considering the main land uses in the Mediterranean drylands, since the driest period of the soil could be assumed to be a phenological summer and the hydrological state of the soil will be more often extreme. There is a need for a better understanding of the effect of rainfall dynamics on different land uses, which would modify the results obtained for bare soils, given that vegetation is one of the main consumers of water.

Finally, it can be seen that for the whole of the selected area it is the organic factors that control the properties of the soils and their hydrodynamics. However, while in humid areas, the dominant factor is soil hydrology, the availability of water, which provides consistent plant cover, regardless of its physiographic position. In arid and semi-arid areas, torrential rainfalls are keys, with a greater incidence in areas with steep slopes, to understand biological factors and soil hydrodynamics. This could be used to establish biodiversity thresholds in the context of climate change. Furthermore, a new challenge could be related to the determination of AWC dynamics from a phenological perspective, which could provide fundamental information for understanding the evolution or loss of plant species in each area and biodiversity. Ultimately, future research should aim at assessing landscape modifications as a result of specific AWC dynamics and identifying which species are most vulnerable.

Funding Funding for open access charge: Universidad de Granada/ CBUA. This study was part of the research project "Incidence of global change in contrasted Mediterranean landscapes," GLOMED-LAND (CSO2016-75898-P), funded by the Ministry of Economy and Competitiveness.

Data Availability Not applicable

Code availability Not applicable

\section{Declarations}

Conflict of interest The authors declare no competing interests.
Open Access This article is licensed under a Creative Commons Attribution 4.0 International License, which permits use, sharing, adaptation, distribution and reproduction in any medium or format, as long as you give appropriate credit to the original author(s) and the source, provide a link to the Creative Commons licence, and indicate if changes were made. The images or other third party material in this article are included in the article's Creative Commons licence, unless indicated otherwise in a credit line to the material. If material is not included in the article's Creative Commons licence and your intended use is not permitted by statutory regulation or exceeds the permitted use, you will need to obtain permission directly from the copyright holder. To view a copy of this licence, visit http://creativecommons.org/licenses/by/4.0/.

\section{References}

Abdalla M, Hastings A, Chadwick DR, Jones DL, Evans CD, Jones MB, Rees RM, Smith P (2018) Critical review of the impacts of grazing intensity on soil organic carbon storage and other soil quality indicators in extensively managed grasslands. Agric Ecosyst Environ 253:62-81. https://doi.org/10.1016/j.agee.2017.10.023

Alcasena-Urdíroz FJ, Vega-García C, Ager AA, Salis M, Nauslar NJ, Mendizabal FJ, Castell R (2019) Forest fire risk assessment and multifunctional fuel treatment prioritization methods in Mediterranean landscapes. Cuadernos de Investigación Geográfica 45:571-600. https://doi.org/10.18172/cig.3716

Al-Shammary AAG, Kouzani AZ, Kaynak A, Khoo SY, Norton M, Gates WP, Al-Maliki M, Rodrigo-Comino J (2020) The performance of the DES sensor for estimating soil bulk density under the effect of different agronomic practices. Geosciences 10:117. https://doi.org/10.3390/geosciences10040117

Angulo-Martínez M, López-Vicente M, Vicente-Serrano SM, Beguería S (2009) Mapping rainfall erosivity at a regional scale: a comparison of interpolation methods in the Ebro Basin (NE Spain). Hydrol Earth Syst Sci 13:1907-1920. https://doi.org/10.5194/hess-13-1907-2009

Asgari N, Ayoubi S, Demattê JAM, Dotto AC (2020) Carbonates and organic matter in soils characterized by reflected energy from 350 $25000 \mathrm{~nm}$ wavelength. J Mt Sci 17:1636-1651. https://doi.org/10. 1007/s11629-019-5789-9

Ayoubi S, Mirbagheri Z, Mosaddeghi MR (2020) Soil organic carbon physical fractions and aggregate stability influenced by land use in humid region of northern Iran. Int Agrophys 34:343-353. https:// doi.org/10.31545/intagr/125620

Behnam A, Mohammad Reza M, Shamsollah A, Elham C, Majid R (2020) Estimation of near-saturated soil hydraulic properties using hybrid genetic algorithm-artificial neural network. Ecohydrol Hydrobiol 20(3):437-449. https://doi.org/10.1016/j.ecohyd.2019. 09.001

Boegh E, Soegaard H, Thomsen A (2002) Evaluating evapotranspiration rates and surface conditions using Landsat TM to estimate atmospheric resistance and surface resistance. Remote Sens Environ 79: 329-343

Bosch JM, Hewlett JD (1982) A review of catchment experiments to determine the effect of vegetation changes on water yield and evapotranspiration. J Hydrol 55:3-23

Bréda N, Huc R, Granier A, Dreyer E (2006) Temperate forest trees and stands under severe drought: a review of ecophysiological responses, adaptation processes and long-term consequences. Ann For Sci 63(6):625-644

Campos I, Villodre J, Carrara A, Calera A (2013) Remote sensing-based soil water balance to estimate Mediterranean holm oak savanna (Dehesa) evapotranspiration under water stress conditions. J Hydrol 494:1-9 
Campos I, González-Piqueras J, Carrara A, Villodre J, Calera A (2016) Estimation of total available water in the soil layer by integrating actual evapotranspiration data in a remote sensing-driven soil water balance. J Hydrol 534:427-439. https://doi.org/10.1016/j.jhydrol. 2016.01.023

Cerdà A (1998) Effect of climate on surface flow along a climatological gradient in Israel: a field rainfall simulation approach. J Arid Environ 38:145-159. https://doi.org/10.1006/jare.1997.0342

Cerdà A, Novara A, Dlapa P et al (2021a) Rainfall and water yield in Macizo del Caroig, Eastern Iberian Peninsula. Event runoff at plot scale during a rare flash flood at the Barranco de Benacancil. Cuadernos de Investigación Geográfica 0. https://doi.org/10. 18172/cig.4833

Cerdà A, Daliakopoulos IN, Terol E, Novara A, Fatahi Y, Moradi E, Salvati L, Pulido M (2021b) Long-term monitoring of soil bulk density and erosion rates in two Prunus Persica (L) plantations under flood irrigation and glyphosate herbicide treatment in La Ribera district, Spain. J Environ Manag 282:111965

Cortesi N, Gonzalez-Hidalgo JC, Brunetti M, Martin-Vide J (2012) Daily precipitation concentration across Europe 1971-2010. Nat Hazards Earth Syst Sci 12(9):2799-2810

Cortesi N, Gonzalez-Hidalgo JC, Brunetti M, De Luis M (2014) Spatial variability of precipitation in Spain. Reg Environ Chang 14:17431749. https://doi.org/10.1007/s10113-012-0402-6

Damaneh E, Hadi MJ, Damaneh HE, Behnia M, Khoorani A, Tiefenbacher JP (2021) Testing possible scenario-based responses of vegetation under expected climatic changes in Khuzestan Province. Air, Soil Water Res 14. SAGE Publications Ltd STM:11786221211013332. https://doi.org/ $10.1177 / 11786221211013332$

De Luis M, Gonzalez Hidalgo JC, Brunetti M, Longares LA (2011) Precipitation concentration changes in Spain 1946-2005. Nat Hazards Earth Syst Sci 11:1259-1265. https://doi.org/10.5194/ nhess-11-1259-2011

Desjardins T, Turcq B, Lézine AM, Nguetnkam JP, Mandeng-Yogo M, Cetin F, Achoundong G (2020) The origin of the forest-grassland mosaic of central Cameroon: what we learn from the isotopic geochemistry of soil organic matter. The Holocene 30(10):1391-1399. https://doi.org/10.1177/0959683620932963

Dlamini P, Chivenge P, Chaplot V (2016) Overgrazing decreases soil organic carbon stocks the most under dry climates and low soil pH: a meta-analysis shows. Agric Ecosyst Environ 221:258-269. https://doi.org/10.1016/j.agee.2016.01.026

Domingo F, Villagarcía L, Brenner AJ, Puigdefábregas J (1999) Evapotranspiration model for semi-arid shrub-lands tested against data from SE Spain. Agric For Meteorol 95:67-84. https://doi.org/ 10.1016/S0168-1923(99)00031-3

Dong C, MacDonald G, Okin GS, Gillespie TW (2019) Quantifying drought sensitivity of Mediterranean climate vegetation to recent warming: a case study in Southern California. Remote Sens 11: 2902. https://doi.org/10.3390/rs 11242902

Dore MHI (2005) Climate change and changes in global precipitation patterns: What do we know? Environ Int 31:1167-1181. https:// doi.org/10.1016/j.envint.2005.03.004

Dunkerley DL (2002) Infiltration rates and soil moisture in a groved mulga community near Alice Springs, arid central Australia: evidence for complex internal rainwater redistribution in a runoffrunon landscape. J Arid Environ 51(2):199-219. https://doi.org/10. 1006/jare.2001.0941

Fernández RJ, Trillo N (2005) La textura del suelo como fuente de heterogeneidad; sus efectos sobre la oferta de agua para las plantas, en Oesterheld M, Aguiar MR, Ghersa CM and Paruelo JM (ed) La heterogeneidad de la vegetación de los agroecosistemas. Fac. Agronomía Univ. Buenos Aires, Buenos Aires, pp 171-192

Fernandez-Anez N, Krasovskiy A, Müller M, Vacik H, Baetens J, Hukić E, Solomun MK et al (2021) Current wildland fire patterns and challenges in Europe: a synthesis of national perspectives. Air, Soil
Water Res 14(SAGE Publications Ltd STM):11786221211028184. https://doi.org/10.1177/11786221211028185

Ferreras Chasco C (2000) Factores mesológicos de la vegetación, en Meaza $G$ (ed) Metodología y práctica de la Biogeografía. Ediciones del Serbal, Barcelona, pp 17-76

Gabarrón-Galeote MA, Ruiz-Sinoga JD, Quesada MA (2013) Influence of aspect in soil and vegetation water dynamics in dry Mediterranean conditions: functional adjustment of evergreen and semi-deciduous growth forms. Ecohydrology 6:241-255. https:// doi.org/10.1002/eco.1262

Gallart F, Llorens P, Latron J, Regüés D (2002) Hydrological processes and their seasonal controls in a small Mediterranean mountain catchment in the Pyrenees. Hydrol Earth Syst Sci 6(3):527-537

Givi J, Prasher SO, Patel RM (2004) Evaluation of pedotransfer functions in predicting the soil water contents at field capacity and wilting point. Agric Water Manag 70(2):83-96

Gomes Marques I, Nascimento J, Cardoso RM, Miguéns F, Condesso de Melo MT, Soares PMM, Gouveia CM, Kurz Besson C (2019) Mapping the suitability of groundwater-dependent vegetation in a semi-arid Mediterranean area. Hydrol Earth Syst Sci 23:3525-3552. https://doi.org/10.5194/hess-23-3525-2019

Grayson RB, Wester AW, Chiew FHS, Blöschl G (1997) Preferred states in spatial soil moisture patterns: local and nonlocal controls. Water Resour Res 33(12):2897-2908

Guillot E, Hinsinger P, Dufour L, Roy J, Bertrand I (2019) With or without trees: resistance and resilience of soil microbial communities to drought and heat stress in a Mediterranean agroforestry system. Soil Biol Biochem 129:122-135. https://doi.org/10.1016/j. soilbio.2018.11.011

Guo Y, Huang S, Huang Q, Wang H, Fang W, Yang Y, Wang L (2019) Assessing socioeconomic drought based on an improved Multivariate Standardized Reliability and Resilience Index. J Hydrol 568:904-918. https://doi.org/10.1016/j.jhydrol.2018.11.055

He X, Wada Y, Wanders N, Sheffield J (2017) Intensification of hydrological drought in California by human water management. Geophys Res Lett 44:1777-1785. https://doi.org/10.1002/ 2016GL071665

IBM Corp. (2017) Released, 2017. IBM SPSS Statistics for Windows, Version 25.0. Armonk, New York.

Imeson AC, Lavee H (1998) Soil erosion and climate change: the transect approach and the influence of scale. Geomorphology 23:219-227. https://doi.org/10.1016/S0169-555X(98)00005-1

IPCC (Intergovernmental Panel on Climate Change) (2014) Fifth assessment report. IPCC, http://ipcc.ch/report/ar5/. Accessed 27 May 2019.

IPCC (Intergovernmental Panel on Climate Change) (2019) 2019 refinement to the 2006 IPCC guidelines for national greenhouse gas inventories. https://www.ipcc.ch/report/2019-refinement-to-the-2006ipcc-guidelines-for-national-greenhouse-gas-inventories/. Accessed 27 May 2019.

Jodar-Abellan A, Fernández-Aracil P, Melgarejo-Moreno J (2019a) Assessing water shortage through a balance model among transfers, groundwater, desalination, wastewater reuse, and water demands (SE Spain). Water 11:1009. https://doi.org/10.3390/w11051009

Jodar-Abellan A, López-Ortiz MI, Melgarejo-Moreno J (2019b) Wastewater treatment and water reuse in Spain. Current Situation and Perspectives. Water 11:1551. https://doi.org/10.3390/ w11081551

Joffre R, Rambal S (1993) How tree cover influences the water balance of Mediterranean rangelands. Ecology 74(2):570-582

Jordano P, Zamora R, Marañón T, Arroyo J (2002) Claves ecológicas para la restauración del bosque mediterráneo. Aspectos demográficos, ecofisiológicos y genéticos. Ecosistemas 11(1):8392 
Katz R, Brush G, Parlange M (2005) Statistics of extremes: modeling ecological disturbances. Ecology 86:1124-1134. https://doi.org/10. 1890/04-0606

Kirkham MB (2005) Field capacity, wilting point, available water, and the non-limiting water range. In: Kirkham MB (ed) Principles of soil and plant water relations. Academic Press, Burlington, pp 101-115. https://doi.org/10.1016/B978-012409751-3/50008-6

Klausmeyer KR, Shaw MR (2009) Climate change, habitat loss, protected areas and the climate adaptation potential of species in Mediterranean ecosystems worldwide. PLoS One 4:e6392. https:// doi.org/10.1371/journal.pone.0006392

Lado M, Paz A, Ben-Hur M (2004) Organic matter and aggregate-size interactions in saturated hydraulic conductivity. Soil Sci Soc Am J 68:234-242. https://doi.org/10.2136/sssaj2004.2340

Laio F, Porporato A, Ridolfi L, Rodriguez-Iturbe I (2001) Plants in water controlled ecosystems: active role in hydrologic processes and response to water stress: II. Probabilistic soil moisture dynamics. Adv Water Resour 24(7):707-723

Larcher W (1995) Physiological plant ecology, $3^{\mathrm{a}}$ edn. Springer-Verlag, Berlin

Lemus-Canovas M, Lopez-Bustins J (2016) Variabilidad espaciotemporal de la precipitación en el sur de Cataluña y su relación con la oscilación del mediterráneo occidental (WEMO). In: Actas del X Congreso Internacional AEC: Clima, sociedad, riesgos y ordenación del territorio. Alicante. https://doi.org/10.14198/ XCongresoAECAlicante2016-21

Li Y, Jiang Z, Yu Y, Shan Z, Lan F, Yue X, Liu P, Gyasi-Agyei Y, Rodrigo-Comino J (2020) Evaluation of soil erosion and sediment deposition rates by the $137 \mathrm{Cs}$ fingerprinting technique at different hillslope positions on a catchment. Environ Monit Assess 192:717. https://doi.org/10.1007/s10661-020-08680-w

Llorens P, Latron J, Gallart F (2003) Dinámica espacio-temporal de la humedad del suelo en un área de montaña mediterránea. Cuencas experimentales de Vallcebre (Alto LLobregat). Estudios de la Zona No Saturada del Suelo 6:71-76

Lobo Do Vale R, Besson CK, Caldeira M, Chaves MM, Pereira JS (2019) Drought reduces tree growing season length but increases nitrogen resorption efficiency in a Mediterranean ecosystem. Biogeosciences 16:1265-1279. https://doi.org/10.5194/bg-16-1265-2019

Martínez-Fernández J (1996) Variabilidad espacial de las propiedades físicas e hídricas de los suelos en medio semiárido mediterráneo. Universidad de Murcia, Murcia

Martínez-Fernández J, Ceballos-Barbancho A, Luengo-Ugidos M A (2001) La sequía edáfica en la cuenca del Duero. Ecosistemas 10(3).

Martínez-Torres HL, Oceguera-Salazar KA, Garduño-Mendoza E, Carlón-Allende T, Jardel-Pelaez E, Quintero-Gradilla SD, Rodríguez JM, Cruz-Zamora M, Pérez-Salicrup DR (2019) Participatory workshops with experts on fire environments in Mexico to generate information on forest fuel beds. Gen. Tech. Rep. PSW-GTR-261 (English). Department of Agriculture, Forest Service, Pacific Southwest Research Station, Albany.

Martin-Vide J (2004) Spatial distribution of a daily precipitation concentration index in peninsular Spain. Int J Climatol 24(8):959-971. https://doi.org/10.1002/joc. 1030

Martin-Vide J, Lopez-Bustins JA (2006) The western Mediterranean oscillation and rainfall in the Iberian Peninsula. Int J Climatol 26: $1455-1475$

Medrano H, Bota J, Cifre J, Flexas J, Ribas-Carbó M, Gulías J (2007) Eficiencia en el uso del agua por las plantas. Investigaciones Geográficas 43:63-84. https://doi.org/10.14198/INGEO2007.43.04

Mohammed S, Al-Ebraheem A, Holb IJ et al (2020) Soil management effects on soil water erosion and runoff in Central Syria - a comparative evaluation of general linear model and random forest regression. Water 12:2529. https://doi.org/10.3390/w12092529

Nardini A, Lo Gullo MA, Trifilò P, Salleo S (2014) The challenge of the Mediterranean climate to plant hydraulics: responses and adaptations. Environ Exp Bot 103:68-79. https://doi.org/10.1016/j. envexpbot.2013.09.018

Negese A, Fekadu E, Getnet H (2021) Potential soil loss estimation and erosion-prone area prioritization using RUSLE, GIS, and remote sensing in Chereti Watershed, Northeastern Ethiopia. Air, Soil Water Res 14:1178622120985814. https://doi.org/10.1177/ 1178622120985814

Negri DH, Gollehon NR, Aillery MP (2005) The effects of climatic variability on US irrigation adoption. Clim Chang 69:299-323. https://doi.org/10.1007/s10584-005-1817-6

Novara A, La Mantia T, Rühl J, Badalucco L, Kuzyakov Y, Gristina L, Laudicina VA (2014) Dynamics of soil organic carbon pools after agricultural abandonment. Geoderma 235-236:191-198. https:// doi.org/10.1016/j.geoderma.2014.07.015

Olcina-Cantos J (2017) Incremento de episodios de inundación por lluvias de intensidad horaria en el sector central del litoral mediterráneo español: análisis de tendencias en Alicante. Sémata Ciencias Sociais e Humanidades 29:143-163

Panagos P, Meusburger K, Ballabio C, Borrelli P, Alewell C (2014) Soil erodibility in Europe: a high-resolution dataset based on LUCAS. Sci Total Environ 479-480:89-200. https://doi.org/10.1016/j. scitotenv.2014.02.010

Peña-Angulo D, Estrany J, García-Comendador J, Fortesa J, TomàsBurguera M, Company J, Alorda B, Nadal-Romero E (2021) Influence of weather types on the hydrosedimentary response in three small catchments on the Island of Mallorca, Spain. Environ Res 192:110324. https://doi.org/10.1016/j.envres.2020.110324

Pendergrass AG, Hartmann DL (2014) Changes in the distribution of rain frequency and intensity in response to global warming. J Clim 27: 8372-8383. https://doi.org/10.1175/JCLI-D-14-00183.1

Peñuelas J, Lloret F, Montoya R (2001) Severe drought effects on Mediterranean woody flora in Spain. For Sci 47(2):214-218

Pulido-Fernández M, Schnabel S, Lavado-Contador JF, Miralles Mellado I, Ortega Pérez R (2013) Soil organic matter of Iberian open woodland rangelands as influenced by vegetation cover and land management. Catena 109:13-24. https://doi.org/10.1016/j.catena.2013.05. 002

Rahmati O, Panahi M, Kalantari Z, Soltani E, Falah F, Dayal KS, Mohammadi F, Deo RC, Tiefenbacher J, Tien Bui D (2019) Capability and robustness of novel hybridized models used for drought hazard modeling in southeast Queensland, Australia. Sci Total Environ 718:134656. https://doi.org/10.1016/j.scitotenv. 2019.134656

Rodrigo-Comino J, Senciales JM, Sillero-Medina JA, Gyasi-Agyei Y, Ruiz-Sinoga JD, Ries JB (2019) Analysis of weather-type-induced soil erosion in cultivated and poorly managed abandoned sloping vineyards in the Axarquía Region (Málaga, Spain). Air, Soil Water Res 12:1178622119839403.https://doi.org/10.1177/ 1178622119839403

Rodrigo-Comino J, Senciales-González JM, Yu Y, Salvati L, GiménezMorera A, Cerdà A (2021) Long-term changes in rainfed olive production, rainfall and farmer's income in Bailén (Jaén, Spain). EuroMediterr J Environ Integr 6:58. https://doi.org/10.1007/s41207021-00268-1

Ruiz Sinoga JD, Gabarrón-Galeote MA, Martínez-Murillo JF, GarcíaMarín R (2011) Vegetation strategies for soil water consumption along a pluviometric gradient in southern Spain. Catena 84:12-20. https://doi.org/10.1016/j.catena.2010.08.011

Ruiz-Sinoga JD, Romero Diaz A (2010) Soil degradation factors along a Mediterranean pluviometric gradient in Southern Spain. Geomorphology 118(3-118):359-368. https://doi.org/10.1016/j. geomorph.2010.02.003

Ruiz-Sinoga JD, Romero-Diaz A, Ferre-Bueno E, Martínez-Murillo JF (2010a) The role of soil surface conditions in regulating runoff and erosion processes on a metamorphic hillslope (Southern Spain). Soil 
surface conditions, runoff and erosion in Southern Spain. Catena 80(2):131-139. https://doi.org/10.1016/j.catena.2009.09.007

Ruiz-Sinoga JD, Martínez-Murillo JF, Gabarrón-Galeote MA, GarcíaMarín R (2010b) The effects of soil moisture variability on the vegetation pattern in Mediterranean abandoned fields (Southern Spain). Catena 85(1):1-11. https://doi.org/10.1016/j.catena.2010. 11.004

Senciales-González JM, Rodrigo-Comino J, Smith P (2020) Surveying topographical changes and climate variations to detect the urban heat island in the city of Málaga (Spain). Cuadernos de Investigación Geográfica 46:521-543. https://doi.org/10.18172/ cig. 4228

Shukla MK, Lal R, Ebinger M (2006) Determining soil quality indicators by factor analysis. Soil Tillage Res 87:194-204

Shufla MK, Lal R, Ebinger, M (2006) Determining soil quality indicators by factor analysis. Soil Tillage Res 87:194-204. https://doi.org/10. 1016/j.still.2005.03.011
Sillero-Medina JA, Hueso-González P, Ruiz-Sinoga JD (2019a) Caracterización de los procesos hidrogeomorfológicos en el Mediterráneo. In: Romojaro R (ed) Las Humanidades en el mundo digital/El mundo digital en las Humanidades. Tirant Humanidades, Valencia, pp 59-73

Sillero-Medina JA, Hueso-González P, Ruiz-Sinoga JD (2019b) La precipitación geomorfológica como elemento clave en el modelado del paisaje mediterráneo. Boletín de la Asociación de Geógrafos Españoles 82(2780):1-40. https://doi.org/10.21138/bage.2780

Terradas J (2001) Ecología de la vegetación. De la ecofisiología de las plantas a la dinámica de comunidades y paisaje. Omega, Barcelona

Vidal A, Pinglo F, Durand H, Devauxros C, Maillet A (1994) Evaluation of a temporal fire risk index in Mediterranean forests from NOAA thermal IR. Remote Sens Environ 49(3):296-303

Wang K, Dickinson RE (2012) A review of global terrestrial evapotranspiration: observation, modeling, climatology, and climatic variability. Rev Geophys 50:54 